\title{
Atevirdine Mesylate
}

National Cancer Institute

\section{Source}

National Cancer Institute. Atevirdine Mesylate. NCI Thesaurus. Code C73148.

A mesylate salt form of atevirdine, a non-nucleoside reverse transcriptase inhibitor.

Atevirdine is active against AZT-resistant virus strains. 